\title{
Molecular profiles of Quadriceps muscle in myostatin-null mice reveal PI3K and apoptotic pathways as myostatin targets
} Ilham Chelh ${ }^{1}$, Bruno Meunier ${ }^{1}$, Brigitte Picard ${ }^{1}$, Mark James Reecy ${ }^{2}$,
Catherine Chevalier $^{3}$, Jean-François Hocquette ${ }^{1}$ and Isabelle Cassar-Malek ${ }^{* 1}$

Address: ' INRA, UR1213, Unité de Recherches sur les Herbivores, Equipe Croissance et Métabolisme du Muscle, Theix, F-63122 Saint-GenèsChampanelle, France, ${ }^{2}$ Iowa State University, Animal Science Dept, 2255 Kildee Hall, Ames, IA 50011-3150, USA and ${ }^{3}$ Plateforme Puces à ADN, Ouest Génopole, U915, Institut du Thorax, Faculté de Médecine 1, rue Gaston Veil, 44035 Nantes cédex, France

Email: Ilham Chelh - ilham.chelh@clermont.inra.fr; Bruno Meunier - bruno.meunier@clermont.inra.fr; Brigitte Picard - Brigitte.Picard@clermont.inra.fr; Mark James Reecy - jreecy@iastate.edu;

Catherine Chevalier - catherine.chevalier@nantes.inserm.fr; Jean-François Hocquette - Jean-Francois.Hocquette@clermont.inra.fr; Isabelle Cassar-Malek* - isabelle.cassar-malek@clermont.inra.fr

* Corresponding author

Published: 27 April 2009

BMC Genomics 2009, 10:196
Received: 18 November 2008

Accepted: 27 April 2009

This article is available from: http://www.biomedcentral.com/I47I-2/64/I0/196

(c) 2009 Chelh et al; licensee BioMed Central Ltd.

This is an Open Access article distributed under the terms of the Creative Commons Attribution License (http://creativecommons.org/licenses/by/2.0), which permits unrestricted use, distribution, and reproduction in any medium, provided the original work is properly cited.

\begin{abstract}
Background: Myostatin (MSTN), a member of the TGF- $\beta$ superfamily, has been identified as a negative regulator of skeletal muscle mass. Inactivating mutations in the MSTN gene are responsible for the development of a hypermuscular phenotype. In this study, we performed transcriptomic and proteomic analyses to detect altered expression/abundance of genes and proteins. These differentially expressed genes and proteins may represent new molecular targets of MSTN and could be involved in the regulation of skeletal muscle mass.
\end{abstract}

Results: Transcriptomic analysis of the Quadriceps muscles of 5-week-old MSTN-null mice $(n=4)$ and their controls $(n=4)$ was carried out using microarray (human and murine oligonucleotide sequences) of 6,473 genes expressed in muscle. Proteomic profiles were analysed using twodimensional gel electrophoresis coupled with mass spectrometry. Comparison of the transcriptomic profiles revealed 192 up- and 245 down- regulated genes. Genes involved in the PI3K pathway, insulin/IGF pathway, carbohydrate metabolism and apoptosis regulation were upregulated. Genes belonging to canonical Wnt, calcium signalling pathways and cytokine-receptor cytokine interaction were down-regulated. Comparison of the protein profiles revealed 20 up- and 18 down-regulated proteins spots. Knockout of the MSTN gene was associated with up-regulation of proteins involved in glycolytic shift of the muscles and down-regulation of proteins involved in oxidative energy metabolism. In addition, an increased abundance of survival/anti-apoptotic factors were observed.

Conclusion: All together, these results showed a differential expression of genes and proteins related to the muscle energy metabolism and cell survival/anti-apoptotic pathway (e.g. DJ-I, PINKI,

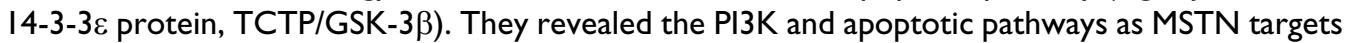
and are in favour of a role of MSTN as a modulator of cell survival in vivo. 


\section{Background}

Myostatin (MSTN), a member of the TGF- $\beta$ superfamily, has emerged as a key factor of muscle development and maintenance of muscle mass homeostasis [1]. This has strengthened the idea that MSTN is a potential target for novel therapeutic strategies to improve the disease symptoms with potential long-term benefits in a variety of muscular dystrophies [2], or for improving the management of muscular growth in livestock animals [3].

Inactivating mutations of the MSTN gene are responsible for the development of a hypermuscular phenotype in cattle [4,5], dogs [6], mice [7] and humans [8]. The hypermuscular phenotype associated with constitutive MSTN loss-of-function results from both hyperplasia (increased number of fibers) and hypertrophy (increased size of individual fibers). An hypermuscular phenotype of the same magnitude as that observed for constitutive knockout has also been observed in mice with a conditional MSTN knockout (postnatal inactivation of MSTN) generated by a Cre-Lox system [9]. This demonstrated that MSTN modulates the muscle mass throughout development. The ability of MSTN to control myoblast cell proliferation and differentiation has been demonstrated. Examination of the molecular action of MSTN has revealed an inhibitory influence on proliferation through the control of cell cycle progression $[10,11]$. MSTN also inhibits myoblast differentiation [12] partially through a decreased expression of Myogenic Regulatory Factors (reviewed by [13]). Myogenin and p21CKI have been identified as the major physiological targets of endogenous MSTN in murine cells [14]. MSTN has also been shown to negatively regulate satellite cell activation and self-renewal [15] and this action may involve a regulation of Pax7 [16]. Furthermore, we recently demonstrated that MSTN can regulate satellite cell proliferation via regulation of WNT4 [17].

Recent data established that MSTN induces muscle atrophy. In mice, muscle disuse-induced atrophy generated by hindlimb unloading is associated with a reversible increase in MSTN mRNA abundance [18]. MSTN has been implicated in muscle wasting in various diseases (HIV, cachexia, cancer, Duchenne's muscular dystrophy) and ageing [19]. Transgenic mice that overexpress MSTN selectively in skeletal muscle have lower muscle mass [20]. In adult rats, ectopic MSTN expression induces atrophy of skeletal muscle as shown by a significant decrease in muscle mass, fiber cross-sectional area and protein content [21]. This is associated with decreased expression of genes structural proteins (myosin heavy chain IIb, troponin I and desmin) and myogenic transcription factors. Moreover, inhibition of MSTN rescues the muscular atrophy of caveolin-3-deficient mice [22] and protects against muscle atrophy due to glucocorticoid treatment [23]. If some of the mechanisms by which MSTN contributes to atrophy have been clarified, e.g. FOXO1 activation and subsequent activation of ubiquitin proteolytic system [24], the relative contribution of MSTN to the regulation of the balance between atrophic and hypertrophic processes in muscle remains to be further elucidated. Some questions remain to be answered such as the possibility that MSTN might inhibit muscle hypertrophy rather than induce atrophy $[24,25]$.

We have previously analysed the metabolic profile of double-muscled cattle [26] and more recently the molecular profiles in muscle in the context of MSTN loss-of-function $[27,28]$ and hypothesised that these should help in the understanding of molecular mechanisms by which MSTN regulates muscle mass homeostasis. The main objective of the present study was to identify MSTN targets involved in the regulation of muscle mass. For this, we examined the transcriptional and proteomic profiles in the Quadriceps muscle of MSTN-null mice and their control littermates. The originality of this work was to combine two genomic approaches, namely transcriptomics and proteomics, providing complementary data.

\section{Results}

Transcriptomic profiles in myostatin-null mice muscle

To search for novel candidate MSTN targets, we used oligonucleotide microarrays (human and murine oligonucleotide sequences) of 6,473 genes expressed in muscle. We examined mRNA expression in individual samples from 4 constitutive MSTN-null and 4 control littermates. A reference sample allowing hybridization with detection of 57 to $68 \%$ reliable spots was used to compare the patterns of muscle gene expression between groups of mice. The hybridization results showed that, among 6,473 genes represented on the chip, an average of 2,496 (39\%) gave valid expression values. Significance analysis of microarray (SAM) was conducted to detect statistically significant expression changes. In total, SAM analysis revealed the differential expression of 192 up- and 245 down- regulated genes (FDR $<5 \%$, see additional files 1 and 2).

Bioinformatic analysis indicated that genes belonging to the Phosphatidyl Inositol 3-kinase (PI3K) pathway, insulin/IGF pathway protein kinase $\beta$ signalling, carbohydrate metabolism, cell differentiation were up-regulated (Table $1)$. Conversely, genes belonging to the canonical Wnt signalling pathway, calcium signalling pathway and cytokine-cytokine receptor interaction were down-regulated (Table 1). Twenty-three of the differentially expressed genes encoded for transcription factors of which 8 were up-regulated (e.g. foxa3) and 15 were down-regulated (e.g. Lef1). 
Table I: Distribution of differential genes in myostatin-null mice vs control mice according to KEGG pathways.

\begin{tabular}{|c|c|c|c|c|c|c|}
\hline \#Entity KEGG & Down regulated genes & $\mathbf{N}=$ & Up regulated genes & $\mathbf{N}=$ & Unadj. P value & Adj. P value \\
\hline $\begin{array}{l}\text { Phosphatidylinositol } \\
\text { signaling system }\end{array}$ & No genes & 0 & $\begin{array}{c}\text { InpplI, PIK3R3, PIK3CG } \\
\text { PLCGI }\end{array}$ & & & \\
\hline Insulin signaling pathway & Gsk3b & 1 & $\begin{array}{l}\text { Ppp I cb, PTPRF, PIK3R3, } \\
\text { PIK3CG, PRKARIB }\end{array}$ & 5 & I.05E-0| & 1 \\
\hline mTOR signaling pathway & No genes & 0 & MO25, PIK3R3, PIK3CG & 3 & I.09E-0I & 1 \\
\hline $\begin{array}{l}\text { Chronic myeloid } \\
\text { leukemia }\end{array}$ & No genes & 0 & PIK3R3, PIK3CG, AblI & 3 & I.09E-0I & 1 \\
\hline $\begin{array}{l}\text { T cell receptor signaling } \\
\text { pathway }\end{array}$ & No genes & 0 & PIK3R3, PIK3CG, PLCGI & 3 & I.09E-0I & 1 \\
\hline $\begin{array}{l}\text { Fructose and mannose } \\
\text { metabolism }\end{array}$ & Akrlel, PMM2, Khk, OGT & 4 & No genes & 0 & I.I9E-0I & 1 \\
\hline $\begin{array}{l}\text { ECM-receptor } \\
\text { interaction }\end{array}$ & $\begin{array}{c}\text { LAMC3, Col4a2, COL6AI, } \\
\text { ITGB8, ITGA9 }\end{array}$ & 5 & Col4a4 & I & $2.08 \mathrm{E}-0 \mathrm{I}$ & 1 \\
\hline $\begin{array}{l}\text { Calcium signaling } \\
\text { pathway }\end{array}$ & $\begin{array}{c}\text { PDEIB, Camk2a, CAMK4, } \\
\text { Cacnali, HTR2A, ADORA2A }\end{array}$ & 6 & PLCGI, Ptgfr & 2 & $2.74 \mathrm{E}-0 \mathrm{I}$ & 1 \\
\hline $\begin{array}{l}\text { Regulation of actin } \\
\text { cytoskeleton }\end{array}$ & LimkI, ARPC4 ITGB8, ITGA9 & 4 & $\begin{array}{l}\text { FGF6, Ppp I cb, PIK3R3, } \\
\text { PIK3CG, CFL2, Actb, MYLI }\end{array}$ & 7 & $3.50 \mathrm{E}-0 \mathrm{I}$ & 1 \\
\hline MAPK signaling pathway & Cacnali & 1 & MAP2K7, FGF6, PLA2G6 & 3 & $3.5 I E-0 I$ & 1 \\
\hline $\begin{array}{l}\text { Natural killer cell } \\
\text { mediated cytotoxicity }\end{array}$ & KLRC2 & 1 & PIK3R3, PIK3CG, PLCGI & 3 & $3.5 \mathrm{IE}-0 \mathrm{I}$ & 1 \\
\hline Apoptosis & Atm & 1 & PIK3R3, PIK3CG, PRKARIB & 3 & $3.5 \mathrm{IE}-0 \mathrm{I}$ & 1 \\
\hline Wnt signaling pathway & Gsk3b, LRP5, Camk2a, LEFI & 4 & $\mathrm{CCND} 3$ & 1 & $3.65 \mathrm{E}-0 \mathrm{I}$ & 1 \\
\hline $\begin{array}{l}\text { Leukocyte } \\
\text { transendothelial } \\
\text { migration }\end{array}$ & Cxcll5, Cxcll3 & 2 & PIK3R3, PIK3CG, Actb, PLCGI & 4 & 4.27E-0I & 1 \\
\hline $\begin{array}{l}\text { Cytokine-cytokine } \\
\text { receptor interaction }\end{array}$ & $\begin{array}{c}\text { IL23A CxclI5, CXCR3, ILI7, } \\
\text { CxclI3 }\end{array}$ & 5 & CCL22, CCR7 & 2 & $4.40 \mathrm{E}-0 \mathrm{I}$ & 1 \\
\hline $\begin{array}{l}\text { Toll-like receptor } \\
\text { signaling pathway }\end{array}$ & $\operatorname{Irf3}$ & 1 & PIK3R3, PIK3CG & 2 & 6.09E-0I & 1 \\
\hline $\begin{array}{l}\text { B cell receptor signaling } \\
\text { pathway }\end{array}$ & Gsk3b & 1 & PIK3R3, PIK3CG & 2 & 6.09E-0I & 1 \\
\hline GnRH signaling pathway & Camk2a & 1 & MAP2K7, PLA2G6 & 2 & 6.09E-0I & 1 \\
\hline Axon guidance & Limkl, Gsk3b, Epha2 & 3 & SEMA3A, AbII, CFL2, EFNA4 & 4 & 7.IOE-0I & 1 \\
\hline Focal adhesion & $\begin{array}{l}\text { LAMC3, Gsk3b, Col4a2, } \\
\text { COL6AI, ITGB8, ITGA9 }\end{array}$ & 6 & $\begin{array}{l}\text { CCND3, PppIcb, PIK3R3, } \\
\text { PIK3CG, Actb, Col4a4 }\end{array}$ & 6 & I & 1 \\
\hline $\begin{array}{l}\text { Hedgehog signaling } \\
\text { pathway }\end{array}$ & Gsk3b & 1 & GasI & 1 & I & 1 \\
\hline Alzheimer's disease & Gsk3b, Apoe & 2 & LRPI & 1 & 1 & 1 \\
\hline
\end{tabular}

$\mathrm{N}$ : Number of genes involved in each biological process; Unadj. P value: Unadjusted $\mathrm{P}$ value, $\mathrm{P}$ value from Fisher's exact test without adjusting for multiple comparisons; Adj. $P$ value: adjusted $P$ value, after correction for multiple testing.

Expression of upstream components of the PI3K survival pathway (Akt, GSK-3 $\beta$ ) were surveyed. The steady-state level of Akt mRNA (Table 1) and phosphorylated protein (Table 2) were increased in the muscles of MSTN-null mice. Differential expression of the GSK-3 $\beta$ was confirmed by qPCR and western-blot (Table 2) analyses. In addition, the ratio of serine-9 phosphorylated GSK-3 $\beta /$ GSK-3 $\beta$ ration was increased, which illustrates GSK-3 $\beta$ activation in MSTN-null versus wild-type skeletal muscle (Table 2).

\section{Proteomic profiles in myostatin-null mice muscle}

We have used two-dimensional polyacrylamide gel electrophoresis, high-throughput image analysis and candidate picking, coupled with mass spectrophotometry to investigate the proteome profile of MSTN-null mice vs control littermates. Comparison of the protein profiles using SAM (FDR $<5 \%$ ) revealed the differential abundance of 38 protein spots (20 up-regulated and 18 downregulated) in MSTN-null mice $v s$ wild-type controls. Mass spectrometry analyses allowed the identification of the candidate spots (Table 3). Differential expression was confirmed for some selected proteins by western-blot analysis (Table 2).

Bioinformatic analysis indicated that most of the differential proteins were related to muscle energy metabolism. Enzymes of the citrate cycle (e.g. pyruvate dehydrogenase lipoamide, dihydrolipoamide S-acetyl transferase E2, isocitate dehydrogenase, Succinate dehydrogenase) and the respiratory chain (e.g. ATP synthase F1 beta, ATP synthase D chain, ubiquinol cytochrome c reductase core protein 1, 
Table 2: Differential expression of myostatin targets genes confirmed by qPCR and by western-blot experiments in MSTN-null mice vs their control littermates.

\begin{tabular}{|c|c|c|c|c|}
\hline & Proteomics & Transcriptomics & qPCR & Western-Blot \\
\hline H-FABP & -2.1 & & & -9.1 \\
\hline МYBPH & 3.1 & & & 1.4 \\
\hline MyHCII & & & & 4.9 \\
\hline Syntrophin A & 1.5 & & & 2.8 \\
\hline p-Akt & & & & 2.2 \\
\hline GSK-3 $\beta$ & & -1.9 & -2.4 & \\
\hline GSK-3 $\beta$ (ser9)/GSK-3 $\beta$ & & & & $1.7 \mathrm{t}$ \\
\hline PI3KR3 & & I.I & 1.8 & \\
\hline DJ-I & 1.5 & & 1.7 & 2.2 \\
\hline PINKI & & 1.9 & & 3.4 \\
\hline PTEN & & & $-1.6 \mathrm{t}$ & -1.6 \\
\hline Mortalin & -1.5 & & -1.4 & -2.1 \\
\hline TCTP & 2.7 & & & 1.6 \\
\hline I4-3-3E & 1.8 & & 1.4 & 1.7 \\
\hline mfgf6 & & & 1.9 & \\
\hline
\end{tabular}

Results are expressed as Fold Changes and all the differences have been declared significant $(P<0.05)$ except for some tendencies $(t: P<0.10)$. H-FABP: Heart-Fatty acid binding protein H; MyBP-H: Myosin binding protein H; MyHCll: fast myosin heavy chain isoform; pAkt: phosphorylated Akt; GSK-3 $\beta$ : Glycogen synthase kinase $3 \beta$; GSK-3 $\beta$ (ser9): Glycogen synthase kinase $3 \beta$ (phosphorylated at serine 9); PI3KR3: Phosphatidylinositol 3-kinase regulatory subunit; DJ-I: cancer- and Parkinson's disease-associated protein (park7); PINKI: PTEN-induced putative kinase I; PTEN: tumour-suppressor phosphatase with tensin homology. TCTP: Translationally controlled tumor protein; 14-3-3E: I4-3-3E protein; mfgf6: murine Fibroblast growth factor 6.

NADH-ubiquinone oxidoreductase), and the heart-fatty acid binding protein (H-FABP) were down-regulated (Table 2; Table 3). Conversely two fragments of Glycogen phosphorylase, and enolase 1 (an enzyme of the glycolysis/gluconeogenesis pathway) were up-regulated (Table 3 ). Abundance levels of Guanidinoacetate methyltransferase, which catalyzes the last step of creatine biosynthesis, purine nucleoside phosphorylase, which catalyzes the reversible cleavage of inosine and guanosine to their respective bases hypoxanthine and guanine, and the adenylate kinase 1, which is an important enzyme in cellular adenine nucleotide homeostasis, were also increased. Myosin-binding protein $\mathrm{H}$, which is a protein involved in the contractile apparatus, was revealed to be up-regulated in MSTN-null mice $v s$ wild-type controls and this was confirmed by western-blot analysis (Table 2). Fast glycolytic Myosin Heavy chain isoforms (MyHCII) were also more abundant in MSTN-null mice vs wild-type controls in western-blot experiments (Table 2). $\alpha 1$-Syntrophin was found to be up-regulated in MSTN-null mice (Table 2; Table 3). All together, these data are representative of greater fast glycolytic metabolism in the muscle of MSTNnull mice.

A differential abundance of survival/mortality factors and some chaperones (Table 3 ) was also detected with the down regulation of Hsp alpha crystallin-related B6, Hsp
9A (mortalin), and the up-regulation of Tcp1, TCTP, DJ-1, and 14-3-3E. The differential abundance levels were confirmed by western-blot analyses for mortalin, DJ-1, TCTP and 14-3-3E (Table 2 and Figure 1). All together these data indicate that myostatin inactivation was associated with up-regulation of survival/anti-apoptotic factors, in favour to increased cell survival.

\section{Discussion}

In this study, we have looked for novel myostatin targets and mechanisms involved in the control of muscle homeostasis. For this, we have used a functional genomics strategy, which combined both transcriptomic and proteomic profiling of MSTN-null $v$ s wild-type control skeletal muscle. We hypothesized that examination of molecular profiles in the muscles of young growing mice in the context of MSTN loss-of-function would allow the identification of myostatin downstream targets. However any changes in gene and protein expression may also reflect consequences of loss of MSTN function. Anyway, this approach should give information on direct or indirect MSTN targets by revealing altered physiological pathways. A similar percentage of genes $(17.5 \%)$ and proteins $(15.3 \%)$ were declared to be differentially expressed with both techniques as indicated by the ratio of the number of differential genes and proteins to the total number of genes spotted on chips and proteins detected in 2-DE gels in the 
Table 3: Differentially expressed muscle proteins in myostatin-null mice vs control mice.

\begin{tabular}{|c|c|c|c|c|c|}
\hline Spot no. & Protein name & Relevant Swiss Prot Accession number & pl & Mr (kDa) & FC \\
\hline 1781 & EefIg protein [Mus musculus] & Q8RIN8_MOUSE & 7.02 & 37.178 & Increased 2.8 \\
\hline 1735 & Adenylate kinase I [Mus musculus] & KADI_MOUSE & 5.67 & 21.64 & Increased I.5 \\
\hline 1728 & DJ-I protein [Mus musculus] & PARK7_MOUSE & 6.32 & 20.236 & Increased 1.5 \\
\hline 1690 & $\begin{array}{l}\text { NADH dehydrogenase (ubiquinone) Fe-S } \\
\text { protein } 3 \text { [Mus musculus] }\end{array}$ & NDUS3_MOUSE & 6.67 & 30.302 & Increased 1.7 \\
\hline 1690 & $\begin{array}{l}\text { Guanidinoacetate methyltransferase [Mus } \\
\text { musculus] }\end{array}$ & GAMT_MOUSE & 5.43 & 26.604 & Increased 1.7 \\
\hline 1663 & $\begin{array}{l}\text { Capping protein (actin filament) muscle } \\
\text { Z-line, beta isoform a [Mus musculus] }\end{array}$ & A2AMV4_MOUSE & 5.47 & 31.611 & Increased 1.4 \\
\hline 1593 & $\begin{array}{l}\text { Capping protein (actin filament) muscle } \\
\text { Z-line, alpha } 2 \text { [Mus musculus] }\end{array}$ & Q3UBZ3_MOUSE & 5.57 & 33.118 & Increased 1.4 \\
\hline 1673 & $\begin{array}{l}\text { Muscle glycogen phosphorylase [Mus } \\
\text { musculus] }\end{array}$ & PYGM_MOUSE & 6.65 & 97.681 & Increased 2.4 \\
\hline 1894 & $\begin{array}{l}\text { Glycogen phosphorylase, muscle form (EC } \\
\text { 2.4.I.I) (Myophosphorylase) [Mus musculus] }\end{array}$ & PYGM_MOUSE & 6.65 & 97.094 & Increased 1.7 \\
\hline 1393 & Enolase $\mathrm{I}$, alpha non-neuron [Mus musculus] & ENOA_MOUSE & 6.37 & 47.453 & Increased I.3 \\
\hline 1230 & t-complex protein I [Mus musculus] & TCPAI_MOUSE & 5.82 & 60.867 & Increased 1.7 \\
\hline 1164 & Myosin binding protein $\mathbf{H}$ [Mus musculus] & MYBPH_MOUSE & 6.21 & 53.065 & Increased 3.1 \\
\hline 1166 & Myosin binding protein $\mathbf{H}$ [Mus musculus] & MYBPH_MOUSE & 6.09 & 53.065 & Increased I.5 \\
\hline$|73|$ & $\begin{array}{l}\text { Translationally-controlled tumor protein } \\
\text { (TCTP) (p23) (21 kDa polypeptide) (p21) } \\
\text { [Mus musculus] }\end{array}$ & TCTP_MOUSE & 4.76 & 19.45 & Increased 2.7 \\
\hline 1703 & $\begin{array}{l}\text { I4-3-3 protein epsilon (I4-3-3E) [Mus } \\
\text { musculus] }\end{array}$ & I433E_MOUSE & 4.63 & 29.155 & Increased 1.8 \\
\hline 1706 & $\begin{array}{l}\text { Calpain small subunit I (CSSI) (Calcium- } \\
\text { dependent protease small subunit I) [Mus } \\
\text { musculus] }\end{array}$ & CPNSI_MOUSE & 5.41 & 28.445 & Increased 1.4 \\
\hline 1718 & $\begin{array}{l}\text { Proteasome subunit beta type } 4 \text { precursor } \\
\text { (EC } 3.4 .25 .1 \text { ) (Proteasome beta chain) [Mus } \\
\text { musculus] }\end{array}$ & PSB4_MOUSE & 5.47 & 29.097 & Increased 1.4 \\
\hline 1980 & $\begin{array}{l}\text { Purine nucleoside phosphorylase (EC } \\
\text { 2.4.2.1) (Inosine phosphorylase) (PNP) [Mus } \\
\text { musculus] }\end{array}$ & PNPH_MOUSE & 5.78 & 32.256 & Increased 2.9 \\
\hline 1427 & Alpha-I-syntrophin [Mus musculus] & SNTAI_MOUSE & 6.4 & 53.632 & Increased I.5 \\
\hline 1804 & $\begin{array}{l}\text { Fatty acid binding protein } 3 \text {, muscle and } \\
\text { heart [Mus musculus] }\end{array}$ & FABPH_MOUSE & 5.75 & $|4.8|$ & Decreased 2.1 \\
\hline 1803 & $\begin{array}{l}\text { Fatty acid binding protein } 3 \text {, muscle and } \\
\text { heart [Mus musculus] }\end{array}$ & FABPH_MOUSE & 6.11 & $|4.8|$ & Decreased 2.I \\
\hline 1764 & $\begin{array}{l}\text { heat shock protein, alpha-crystallin-related, } \\
\text { B6 [Mus musculus] }\end{array}$ & HSPB6_MOUSE & 5.64 & 17.567 & Decreased 1.8 \\
\hline 1620 & $\begin{array}{l}\text { Pyruvate dehydrogenase (lipoamide) beta } \\
\text { [Mus musculus] }\end{array}$ & ODPB_MOUSE & 6.41 & 39.254 & Decreased I.4 \\
\hline I57| & $\begin{array}{l}\text { Lactate dehydrogenase 2, B chain [Mus } \\
\text { musculus] }\end{array}$ & LDHB_MOUSE & 5.7 & 36.834 & Decreased 2.4 \\
\hline$|54|$ & $\begin{array}{l}\text { Isocitrate dehydrogenase } 3 \text { (NAD+) alpha } \\
\text { [Mus musculus] }\end{array}$ & IDH3A_MOUSE & 6.27 & 40.069 & Decreased I.3 \\
\hline 1534 & $\begin{array}{l}\text { Isocitrate dehydrogenase } 3 \text { (NAD+) alpha } \\
\text { [Mus musculus] }\end{array}$ & IDH3A_MOUSE & 6.27 & 40.069 & Decreased 1.6 \\
\hline 1407 & $\begin{array}{l}\text { Ubiquinol-cytochrome c reductase core } \\
\text { protein I [Mus musculus] }\end{array}$ & QCRI_MOUSE & 5.81 & 53.446 & Decreased I.3 \\
\hline 1373 & $\begin{array}{l}\text { ATP synthase, } \mathrm{H}+\text { transporting } \\
\text { mitochondrial FI complex, beta subunit } \\
\text { [Mus musculus] }\end{array}$ & AT5FI_MOUSE & 5.19 & 56.265 & Decreased 2.3 \\
\hline 1178 & $\begin{array}{l}\text { Dihydrolipoamide S-acetyltransferase (E2 } \\
\text { component of pyruvate dehydrogenase } \\
\text { complex) [Mus musculus] }\end{array}$ & ODP2_MOUSE & 8.81 & 68.473 & Decreased 1.5 \\
\hline 1084 & Heat shock protein 9A [Mus musculus] & GRP75_MOUSE & 5.91 & 73.768 & Decreased I.5 \\
\hline 1691 & $\begin{array}{l}\text { NADH-ubiquinone oxidoreductase } 30 \mathrm{kDa} \\
\text { subunit, mitochondrial precursor [Mus } \\
\text { musculus] }\end{array}$ & NUGM_MOUSE & 6.4 & 30.189 & Decreased I.3 \\
\hline 1139 & Serum albumin precursor [Mus musculus] & ALBU_MOUSE & 5.75 & 68.648 & Decreased I.3 \\
\hline 1109 & Serum albumin precursor [Mus musculus] & ALBU_MOUSE & 5.75 & 68.648 & Decreased 1.6 \\
\hline
\end{tabular}


Table 3: Differentially expressed muscle proteins in myostatin-null mice vs control mice. (Continued)

\begin{tabular}{|c|c|c|c|c|c|}
\hline 1739 & $\begin{array}{l}\text { ATP synthase D chain, mitochondrial [Mus } \\
\text { musculus] }\end{array}$ & ATP5H_MOUSE & 5.52 & 18.607 & Decreased 1.3 \\
\hline 1152 & $\begin{array}{l}\text { Succinate dehydrogenase [ubiquinone] } \\
\text { flavoprotein subunit, mitochondrial } \\
\text { precursor [Mus musculus] }\end{array}$ & DHSA_MOUSE & 7.06 & 72.539 & Decreased I.7 \\
\hline 1400 & $\begin{array}{l}\text { Ubiquinol-cytochrome-c reductase complex } \\
\text { core protein I, mitochondrial precursor } \\
\text { [Mus musculus] }\end{array}$ & UQCRI_MOUSE & 5.75 & 52.735 & Decreased I.5 \\
\hline 1608 & $\begin{array}{l}\text { Troponin T, fast skeletal muscle (TnTf) (Fast } \\
\text { skeletal muscle troponin T) (fTnT) [Mus } \\
\text { musculus] }\end{array}$ & TNNT3_MOUSE & 5.26 & 32.09 & Decreased 1.6 \\
\hline
\end{tabular}

Accession number: reference of each protein in Swiss-Prot database; pl: isoelectric point; $\mathrm{Mr}(\mathrm{kDa})$ : molecular weight; FC: Fold-Change

range of $\mathrm{pH} 4-7$, respectively. Transcriptomics and proteomics provided complementary data and led us to analyse both gene expression by $\mathrm{qPCR}$ and protein abundance by western blotting for some candidate targets.

As expected, the expression of several genes and abundance of proteins involved in muscle energy metabolism were altered. Specifically we found an up-regulation of those involved in glycolytic metabolism and a down-regulation of mitochondrial proteins. Similar to previously published results [27-29], this provided additional evidence of a glycolytic shift within skeletal muscle in absence of functional myostatin. Additionally, expression level of $\alpha 1$-syntrophin, a predominant syntrophin isoform in skeletal and cardiac muscle, significantly increased in MSTN-null mice. This result is in agreement with the work of Vandebrouck and co-workers [30], which indicates that $\alpha 1$-syntrophin might play a potential signalling role in the regulation of calcium influx in muscle cells and thereby regulate muscle activity.

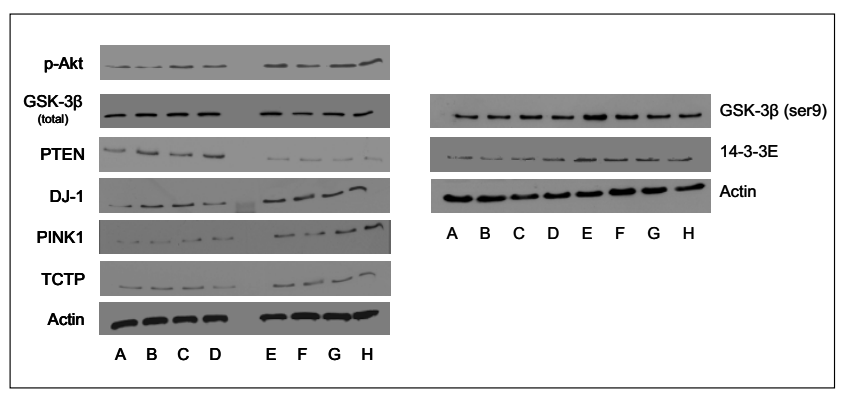

Figure I

Abundance of candidate proteins to be myostatin targets as revealed by western-blotting in the muscles of control and MSTN-null mice. A-D: control mice; E-H: MSTN-null mice. pAkt: phosphorylated akt; GSK-3 $\beta$ : Glycogen synthase kinase $3 \beta$; GSK-3 $\beta$ (ser9): Glycogen synthase kinase $3 \beta$ (phosphorylated at serine 9); DJ-I: cancerand Parkinson's disease-associated protein (park7); PINKI: PTEN-induced putative kinase I; PTEN: tumour-suppressor phosphatase with tensin homology. TCTP: Translationally controlled tumor protein; 14-3-3E: 14-3-3e protein. Actin was used as a loading control protein.

\section{Increased potential for PI3K pathway}

Our study revealed that upstream components of the PI3K/Akt/GSK-3 $\beta$, a signalling network that promotes cell survival and proliferation, were targets of myostatin inactivation. The core of the PI3K signalling pathway begins with PI3K activation and subsequent generation of the second messenger lipid phosphatidyl $(3,4,5)$ triphosphate, which recruits and activates PI-dependent kinase. The latter phosphorylates and activates protein kinase $\mathrm{B} /$ Akt [31]. GSK-3 $\beta$ is a substrate for phosphorylated Akt and is inactivated upon phosphorylation. We detected the differential expression of mRNAs that encode for PIK3R3, PIK3CG, PLCG1, and GSK-3 $\beta$. Increases in the abundance of phophorylated-Akt and in the activation ratio of GSK$3 \beta$ (phosphorylated GSK-3 $\beta$ at serine 9/GSK-3 $\beta$ ) were also detected (Table 2). This finding is original since the PI3K pathway is mainly regulated through post-translational modification namely phosphorylation. Thus, our results indicate that myostatin inactivation resulted in increased potential for PI3K/Akt activation and decreased potential for GSK-3 $\beta$ activity both at the transcriptional and posttranslational levels.

Interestingly, we also detected the differential abundance of factors regulating the PI3K pathway e.g. DJ-1, PTEN and PINK1. DJ-1, a cancer- and Parkinson's disease-associated protein also called park7, protects cells from toxic stresses and is implicated in mitochondria and oxidative stressrelated survival pathways (reviewed in [32]). It associates with chaperonnes including mortalin. DJ-1 has also been reported to be a novel regulator of the PI3K-PTEN pathway [33]. The tumour-suppressor phosphatase with tensin homology (PTEN) is the most important negative regulator of the cell-survival signalling initiated by PI3K (Figure 1). DJ-1 interacts with PTEN-induced putative kinase 1 (PINK1), which encodes a Ser/Thr kinase with a mitochondrial-targeting signal, and collaborate to protect cells against oxidative stress induced cell death [34]. Interestingly, our data show up-regulation of DJ-1 and PINK1 and down-regulation of PTEN both at the transcriptional and protein levels and this could account for activation of the PI3K pathway in MSTN-null mice. 
The PI3K/Akt pathway plays a pivotal role in the promotion of cell proliferation and inhibition of cell death. It plays an important role in at least two signal transductory systems, namely, the Wnt/wingless and PI3K pathways, which influence proliferation and cell survival, respectively. Our data agree well with data that demonstrate a correlation between activation of PI3K pathway and increase in cell size [35] and the activation of Akt, which stimulates muscle hypertrophy and antagonizes the loss of muscle protein [36]. Akt signalling through GSK-3 $\beta$, mTOR (a PI3K-related kinase) and Foxo1 was shown to be associated with skeletal muscle hypertrophy and atrophy processes in humans [37]. Recently, Amirouche and workers have shown that MSTN negatively regulates Akt/mTOR signalling pathway [38]. It was also shown that MSTN activates GSK-3 $\beta$ and decreases cyclin D1 by inhibiting the PI3K/Akt pathway and this has been proposed to be involved in the progression of muscle-disuse atrophy [39]. Lastly, the PI3K/Akt pathway is the major intracellular pathway activated by IGF-I stimulation during myogenesis [40]. A primary effect of GSK-3 $\beta$ inhibition in muscle is to promote myogenic differentiation and it has been proposed that IGF-mediated hypertrophy involves the negative regulation of GSK-3 $\beta$ activity [41].

\section{Altered expression/abundance of factors involved in cell survivallapoptosis}

Our data revealed changes in the expression of genes and proteins related to cell survival/apoptosis pathways. Actually, we detected the down-regulation of some factors (e.g. alpha crystallin-related B6, heat shock protein 9A) and up-regulation of others (e.g. Dad1, survivin, TCTP, 14-3$3 \mathrm{E})$ that may be a signature of increased cell survival and anti-apoptotic processes. Indeed, alpha crystallin-related B6, a heat shock protein 20, is thought to protect cells from apoptosis [42]. Heat shock protein 9A (Mortalin, Grp75), a member of the heat shock protein 70 family, plays a central role in mitochondrial import, energy generation and chaperoning of mis-folded proteins (for review [43]). This factor interacts with the tumor suppressor protein p53 and inactivates its transcriptional activation and apoptotic functions [44]. Up-regulation of mortalin contributes significantly to tumorigenesis [45]. Dad1 (defender against apoptotic death) has been reported to be a programmed cell death suppressor necessary for cell survival in a mammalian cell line [46] and the loss of Dad1 protein triggers apoptosis [47]. Survivin (Birc5) is a member of the inhibitor of apoptosis (IAP) family that prevents apoptotic cell death in various cell types including hematopoietic, endothelial, embryonic and neuronal cells [48]. Translationally controlled tumor protein (TCTP) is involved in the calcium binding and microtubule stabilization [49] and has been implicated in cell growth, cell cycle progression, malignant transformation and in protection of cells against various stress condi- tions and apoptosis [50]. 14-3-3E is a member of the 143-3 family of phosphoserine-binding adapter molecules that mediate a general survival-promoting function through interaction with target proteins, by enhancing pro-survival signalling while suppressing activity of proapoptotic proteins (reviewed by [51]). They are involved in the regulation of apoptosis through multiple interactions with proteins of the core mitochondrial machinery, pro-apoptotic transcription factors and their upstream signalling pathways. One prominent mechanism for the suppression of apoptosis is through 14-3-3-mediated sequestration of pro-apoptotic proteins (e.g. BAD, Bcl-2antagonist of cell death; [52]). Furthermore, 14-3-3 proteins regulate the Akt/mTOR pathway via interaction with PRAS40, a mTOR binding partner [53]. In our study, 143-3E showed greater expression in the hypertrophied muscles of MSTN-null mice. Interestingly, some of the differential proteins detected in our study (e.g. DJ-1, T-complex protein 1 , proteasome $\mathrm{B}$ chain) were reported to belong to the 14-3-3 interacting "phosphoproteome" [54].

Interestingly, in a previous study conducted in the context of MSTN loss of function in cattle [28], we have already found an up-regulation of genes encoding proteins involved in apoptosis (e.g DDX, PDCD6) and a down-regulation of anti-apoptotic genes belonging to the $\mathrm{Bcl} 2 \mathrm{fam}$ ily. Supporting the hypothesis of decreased apoptosis in the muscles of MSTN-null mice, we found that the bioactive fragment of the initiator Caspase 8 was decreased in these mice compared to their littermates (data not shown). The functional significance of proteins related to cell survival/apoptosis to muscle hypertrophy remains to be further studied. However, the results of the present study suggest that MSTN may behave as an arbiter of the survival decision in the muscles. In MSTN-null mice, increased abundance of anti-apoptotic factors probably induces a by-pass of apoptosis and consequently increased cell survival, a process leading to hypertrophy (Figure 1). The involvement of MSTN in apoptosis remains scarce and controversial. There are conflicting results regarding MSTN and apoptosis. It is not clear whether this factor protects myoblasts from apoptosis $[14,55]$ or promotes the apoptotic process $[39,56]$. This discrepancy may be explained by the different experimental conditions in which MSTN effect was examined in vitro (e.g. proliferation $v s$ differentiation phase, myogenic cell lines $v$ s primary myoblast cultures). Although skeletal muscle is considered to be rather resistant to apoptosis partly due to high concentration of endogenous inhibitors (reviewed in [57]), there is evidence that apoptotic events occur in skeletal muscle under physiological (exercise) and pathological conditions (e.g. muscle disuseinduced atrophy, denervation, ageing, dystrophinopathies) and may contribute to atrophy and loss of fibers 
[58-61]. "Myonuclear apoptosis" is a predominant form of apoptosis by which a loss of myonuclei occurs without cell death during muscle atrophy $[62,63]$. This process may have major consequence since (1) the number of myonuclei is a critical determinant for protein synthesis capacity (2) apoptosis within muscle may alter the myonuclear to cytosolic ratio (protein/DNA). Thus, modulation of myonuclear number or myonuclear domain size or both is a mechanism by which MSTN may contribute to muscle homeostasis. Inhibition of apoptosis in the context of MSTN loss-of-function could lead to increased myonucler survival and consequently to increased protein biosynthesis. Thus, this could contribute to the hypertrophic pathway, especially in growing mice. Work is progress to assay apoptotic process in muscles according to MSTN activity.

\section{Conclusion}

In conclusion, integration of transcriptomic and proteomic data indicate that MSTN inactivation could promote survival and resistance to apoptosis in muscle through the PI3K/Akt/GSK-3 $\beta$ survival pathway and through a mechanism that involves regulation of pro- and anti-apoptotic factors. A combination of increased potential for PI3K activation and decreased myonuclear apoptosis could be crucial to muscle hypertrophy in MSTN-null mice (Figure 2).

\section{Methods}

\section{Muscle samples}

The MSTN-null mice have a constitutive invalidation of myostatin gene [7]. These mice were bred at the Iowa State University, were slaughtered at 5 weeks postnatally, were dissected and their muscle masses were weighted. At this age the mice were nearly adults and this developmental stage was chosen in order to dissociate the influence of MSTN on hypertrophy from that of myofiber hyperplasia. Muscle samples were taken from Quadriceps muscle (mixed slow oxidative) immediately after slaughter, frozen in liquid nitrogen and kept at $-80^{\circ} \mathrm{C}$ until protein extraction was performed. The Quadriceps muscle was chosen for the genomic experiments owing to its weight and marked hypertrophy ( $+87 \%$, data not shown).

\section{Microarray experiments}

Transcriptomic analysis was performed with a microarray of 6,473 genes expressed in muscle ("Myochips" available from OUEST-genopole ${ }^{\circledast}$, France) as described in [28]. These Myochips consisted in 6,473 oligonucleotides from human (76\%) and murine (24\%) origin and 919 controls. Microarray experiments were performed according to recently proposed standards (MIAME consortium). Data were incorporated into the BASE database and the NCBI Gene Expression Omnibus (GEO) http:// www.ncbi.nlm.nih.gov/projects/geo/ and are accessible through GEO Series GSE5561 and GSE5456.

Total RNA was extracted from muscle tissue samples with TRIZOL $^{\circledast}$ reagent (Life Technologies) according to the manufacturer's recommendation. The RNA was then purified and treated with DNAse using the RNeasy ${ }^{\otimes}$ Mini kit (Qiagen, France). RNA integrity was checked using Lab Chip Agilent technology, as previously described [28]. Each individual sample was compared to a reference pool consisting of skeletal muscle transcripts isolated from different muscles of four mice lines (Balb, C57bl6, B129) of different age and gender, and from cultured murine myogenic cells (C2C12).

Labeling was performed using a "Pronto Plus Direct Systems" kit (Corning-Promega) according to the supplier's guidelines. Five $\mu \mathrm{g}$ of total RNA was reverse transcribed into cDNA in the presence of cyanine (Cy3-dCTP/Cy5dCTP, Amersham). cDNA purification was performed according to the manufacturer's instructions, and concentration and frequency of incorporation were determined by spectrophotometry. Three chips were hybridized per sample comparison. After washing, the chips were scanned on an Affymetrix $428^{\mathrm{TM}}$ Array Scanner. Images were analyzed using GenePix Pro V6 software (Axon instrument, Inc). Raw intensity data were normalized using the MADSCAN program (http://cardios erve.nantes.inserm.fr/mad/madscan/, 15). In order to identify differentially expressed genes, the $\mathrm{Cy} 3 / \mathrm{Cy} 5$ ratios were statistically analyzed using Significance Analysis of Microarrays (SAM) method (FDR $<5 \%$; [64]). With the available sample size (4 animals per group) and 3 repeated measurements per sample and taking account a test power $(1-\beta)$ set at $80 \%[65,66]$ and the biological variability (Standard Deviation SD $=0.083$ ), the minimum difference was $11 \%$ corresponding to a threshold foldchange (FC) of 1.11. Thus we only retained appropriately powered genes.

\section{Proteomics}

Preparation of muscle samples for 2-DE

Sample preparation was performed according to Bouley et al. [67]. Briefly, frozen muscle tissue $(50-100 \mathrm{mg}$ ) was homogenized in a lysis buffer containing $8.3 \mathrm{M}$ urea, $2 \mathrm{M}$ thiourea, 1\% DTT, 2\% CHAPS and 2\% IPG buffer pH 310 with a polytron and centrifuged at $10,000 \mathrm{~g}$ for $30 \mathrm{~min}$. The supernatant was harvested and protein concentration for each sample was determined as described in the PlusOne 2-DE Quant kit (Amersham Biosciences).

Protein quantification was determined using the 2-DE Quant kit (Amersham Uppsala, Sweden), with bovine serum albumin as a standard. Average amount of protein was $9.6 \mu \mathrm{g} . \mu \mathrm{l}^{-1} \pm 1.48 \mu \mathrm{g} \cdot \mu \mathrm{l}^{-1}$. 


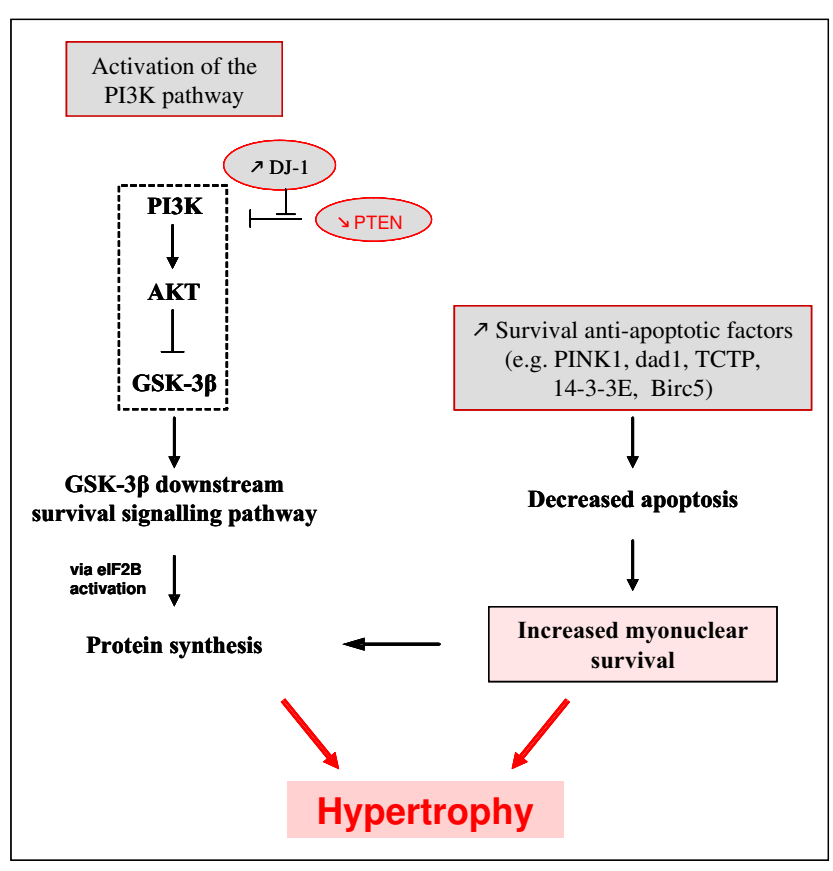

\section{Figure 2}

In MSTN-null mice, regulators of the PI3K pathway and cell survival/apoptosis likely contribute to muscle hypertrophy. PI3K signalling pathway: PI3K, Phosphatidyl Inositol 3 Kinase; Akt, protein kinase B; GSK-3 $\beta$, Glycogen synthase kinase $3 \beta$; elF2B, eukaryotic protein synthesis initiation factor 2B; PTEN, tumour-suppressor phosphatase with tensin homology (the most important negative regulator of the cell survival signalling initiated by PI3K); DJ-I, a cancerand Parkinson's disease-associated protein (a novel regulator of the PI3K-PTEN pathway). Survival/Anti-apoptotic factors: PINKI, PTEN-induced putative kinase; DadI, defender against apoptotic death; TCTP, Translationally controlled tumour protein; I4-3-3E, I4-3-3 protein epsilon; Birc5, survivin.

\section{2-DE separation}

2-DE separation was performed according to the method of Bouley et al. [67]. Briefly, for the first dimension (IEF), proteins were solubilized in a rehydration solution ( $8 \mathrm{M}$ urea, $1 \mathrm{M}$ thiourea, $0.28 \%$ DTT, 2\% CHAPS, 2\% IPG buffer pH 4-7 and 0.01\% CBBR-250). IPG strips, $18 \mathrm{~cm}$, covering a $\mathrm{pH}$ range of 4-7 were rehydrated overnight in $330 \mathrm{ml}$ of this protein solution under low viscosity paraffin oil (sample loading by rehydration). IPG strips containing $700 \mu \mathrm{g}$ of proteins were subjected to IEF (73.5 $\mathrm{kVh}$ ) in a Multiphor II gel apparatus at $20.5^{\circ} \mathrm{C}$. After completion of the IEF, proteins on the strip were equilibrated for $15 \mathrm{~min}$ in a buffer containing $6 \mathrm{M}$ urea, 1\% DTT, 30\% glycerol, $50 \mathrm{mM}$ Tris base, $2 \%$ sodium dodecyl sulphate (SDS), and DTT and then for an additional $15 \mathrm{~min}$ in the same solution except that DTT was replaced by 5\% iodoacetamide and $0.002 \%$ bromophenol blue was added. The
IPG strips were then transferred onto 11\% T, 2.6\% C separating polyacrylamide gels, and proteins were separated in the second dimension using a Hoefer DALTsix system (Hoefer, Scientific Instruments, San Francisco, CA, USA). 2-DE gels were stained using a colloidal CBB G-250 procedure [67] and digitized on a calibrated scanner (ImageScanner, Amersham).

\section{Image and Data analysis}

ImageMaster 2D Platinum software (Amersham Biosciences) was used to match and quantify protein spots on 2-DE gels. Parameters used for spot detection were minimal area $=70$ pixels, smooth factor $=2.0$, and saliency $=$ 20. An artificial reference gel was created combining all the spots present in the different gels. The reference gel was then used for matching of corresponding protein spots between gels. The volume of individual spot was normalized (\% volume) according to the mean volume of 249 protein spots which were strictly common to all gels. Comparisons between groups were performed using SAM statistical test [68]. Differences were declared significant for FDR $<5 \%$. Taking into account the biological variability which is $21 \%$, the power analysis [66] allowed retaining proteins which present a minimum difference of $41 \%$ corresponding to a threshold FC of 1.41.

\section{Identification of spots by Mass Spectrometry}

All differential protein spots were excised from the polyacrylamide gel and placed in a Multiscreen solvinert 96well filtration system plate (Millipore Corp., Bedford, $\mathrm{MA})$. These proteins of interest were digested proteolytically in the plate with 3 volumes of trypsin solution (10 $\mathrm{ng} / \mu \mathrm{L}$; V5111, Promega, Madison, WI) at $37^{\circ} \mathrm{C}$ for $5 \mathrm{~h}$ and extracted with $8-12 \mu \mathrm{L}$ of $\mathrm{ACN}$. The resulting peptide fragments were mixed with an equal volume of CHCA saturated solution in $0.1 \%$ TFA, 50\% aqueous $\mathrm{ACN}$.

Peptide mass fingerprintings (PMF) of tryptic peptides were identified in a positive reflectron mode using a voyager DE Pro MALDI-TOF (Perspective Biosystem, Farminghan, MA, USA). External calibration was performed with a standard peptide solution (Proteomix, LaserBio Labs, Sophia-Antipolis, France). Internal calibration was performed using peptides resulting from auto-digestion of porcine trypsin, with protonated masses of 842.509, 1045.564, and 2211.104 Da. Peptides mass fingerprints were compared with mammalian databases [NCBI http:// www.ncbi.nlm.nih.gov/Database/ and SWISS-PROT http://www.expasy.org/sprot/] using MASCOT and ProFound software [http://www.matrixscience.com and http://prowl.rockefeller.edu, respectively (June 2007 and October 2007)].

The search criteria used were 1 missing trypsin cleavage site, partial methionine oxidation, partial carbamid- 
Table 4: Primer sequences used in quantitative real-time PCR.

\begin{tabular}{lcc}
\hline Gene Symbol & Forward primer & Reverse primer \\
\hline DJ-I & AACACACCCACTGGCTAAGG & GGGCTTGGGCTCTAGTCTTT \\
Ywhae & GAGGTGTTTTGGGGAGTTT & GGCTTCCATACCACCTTCAA \\
HSPA9 & GCCGTTTCCAGTGCAACAAG & GATGCTGCCGTCCTGATGTT \\
GSK-3 3 & CTCTGGCCACCATCCTTATC & GTTCAGGTGGAGTTGGAAGC \\
PTEN & TGCAGAAAGACTTGAAGGTG & ATAAGTTCTAGCTGTGGTGG \\
Pi3Kr3 & ATGAGAACCTGCCGCATTAT & GAATGCACCATCTGGTTTCC \\
mfg6 & ATTGGGAAAGCGGCTATTTGC & CTCGTGTGTTCCACTGATGC \\
mS6R & TTTGATTCTGAAAGCCATGCG & CGGTCCATCAGGATTCTATTG \\
\hline
\end{tabular}

All primer sequences were designed with the Primer3 software.

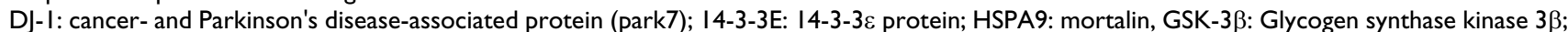
PI3KR3: Phosphatidylinositol 3-kinase regulatory subunit; PTEN: tumour-suppressor phosphatase with tensin homology; mfgf6: murine Fibroblast growth factor 6; mS6R: mouse ribosomal protein S6.

omethylation of cysteine and mass deviation lower than $30 \mathrm{ppm}$. We required at least 5 matched peptides per protein for identification and used the ProFound and MASCOT probabilistic score and the accuracy of the experimental-to-theoretical isoelectric point (pI) and molecular weight $(\mathrm{Mr})$.

\section{Bioinformatic tools}

To understand biological function or molecular mechanism of the main molecular targets of MSTN, we used a set of bioinformatics web tools such as Genomatix, DAVID and PANTHER for gene identification and String for interactions networks between proteins. The data mining allowed to visualize KEGG (Kyoto Encyclopedia of Genes and Genomes) pathway and to classify gene and protein by their function.

\section{Validation of Proteins and genes expression Western blotting}

Western-blotting was used to validate the main differentially expressed proteins. These proteins were separated by gel electrophoresis using SDS-PAGE for $2 \mathrm{~h}$. After migration, the proteins were transferred onto PVDF transfer membrane Millipore (Dutscher Dominique SAS, France). Membranes were then blocked with 5\% non-fat milk in TTBS $1 \times$ buffer containing (blocking solution) and incubated under gentle agitation all the night at room temperature in the presence of the a primary antibodies: DJ-1, 1:2000 dilution of purified rabbit polyclonal anti-DJ-1 antibody (sc 32874, Santa Cruz); MyBP, 1:4000 dilution of purified mouse monoclonal anti-MyBP antibody (H0000 4608-MO1, ABNOVA); TCTP, 1:2000 dilution of purified rabbit polyclonal anti-HRF antibody (sc 30124, Santa Cruz); $14-3-3 \varepsilon, 1: 4000$ dilution of purified goat polyclonal anti-14-3-3e protein antibody (sc 1615, Santa Cruz); $\alpha-1$ syntrophin, 1:500 dilution of purified rabbit polyclonal anti-SNTA1 antibody (sc- 50460, Santa Cruz); H-FABP, 1:2000 dilution of purified rabbit polyclonal anti-H-FABP, was a gift from Dr. Jacques Veerkamp and
Dr. Herman Van Moerkerk (Dept. Biochemistry, Nijmegen, Netherlands) [63]; mortalin, 1:250 dilution of purified mouse monoclonal anti-GRP75 antibody (MAB3584, Clone 419612, R\&D systems); PINK1, 1:2000 dilution of purified rabbit polyclonal anti-PINK1 antibody (sc- 33796, Santa Cruz); GSK-3 $\beta$, 1:2000 dilution of purified rabbit polyclonal anti-GSK-3 $\beta$ antibody (sc9166, Santa Cruz); GSK-3 $\beta$ (ser9), 1:4000 dilution of purified goat polyclonal anti-p-GSK-3 $\beta$ (Ser9) antibody (sc- 11757, Santa Cruz); MyHC, 1:2000 dilution of purified mouse monoclonal anti-MyHC antibody [S5 8H2, lot: 9013-1, obtained under "Noé" project who associates our team and Biocytex company [69] and now this antibody is commercialized by Agro-Bio society]; PTEN, 1:2000 dilution of purified rabbit polyclonal anti-PTEN antibody (sc- 9145, Santa Cruz); p-Akt, 1:2000 dilution of purified rabbit polyclonal anti-p-Akt 1/2/3 (Ser473) antibody (sc- 33437-R, Santa Cruz); Actin, 1:20000 dilution of purified mouse monoclonal anti-actin antibody (IgG2a, Clone AC40, Sigma Chemical Company, St Louis, MO, USA), which are able to bind to its specific protein. The blots were extensively washed with Tris buffer and incubated under gentle agitation with the secondary antibodies (anti-mouse, anti-goat or anti-rabbit IgG combined with conjugated with horseradish peroxidase 1: 20000 dilution) for $1 \mathrm{~h}$. The activity of the enzyme was revealed by Enhanced Chemiluminescence kit (Amersham).

The power analysis [66] allowed retaining proteins which present a minimum difference of $45 \%$ corresponding to a threshold FC of 1.45 .

\section{Real-Time Polymerase Chain Reaction Analysis}

Seven genes shown to be differentially expressed were selected from the results obtained by microarray analysis and by proteomic analysis. The quantitative RT-PCR (qPCR) was realized using SYBR Green I dye. PCRs were performed using gene-specific primers pairs (Table 4 ). The 
absolute quantity of each target gene was determined by using serially diluted standards to generate a standard curve. The concentration in $\mathrm{pg} / \mu \mathrm{mol}$ of each gene was determined by using a linear relationship between amounts of standards cDNA and their Ct (Cycle threshold). Real-Time PCR experiment was controlled using the ribosomal protein S6 as reference gene. The power analysis [66] allowed retaining genes which present a minimum difference of $54 \%$ corresponding to a threshold FC of 1.54 .

\section{Western-blot and RT-PCR data analysis}

The difference of proteins and genes levels between myostatin-null mice and their controls was analyzed by Student t-test. Results are expressed as the mean \pm standard error of mean (SEM). A difference between the two groups was considered significant when $P<0.05$.

\section{Abbreviations}

MSTN: myostatin; SAM: Significance Analysis of Microarrays; DNA: Desoxyribo Nucleic Acid; FC: Fold Change; FDR: False Discovery Rate; PI3K: the Phosphatidyl Inositol 3-kinase.

\section{Authors' contributions}

IC and ICM carried out the experiments. ICM conceived the experimental design in collaboration with $\mathrm{BP}$ and JFH who provided useful advice for data analysis and interpretation. IC and BM were actively involved in data analyses and interpretation. JR bred the experimental animals and provided muscle samples. CC provided the array and skilled advice for microarray analyses. IC and ICM wrote the manuscript. All authors read the manuscript, significantly contributed either to the presentation, the interpretation or the discussion of the results, and were highly involved in writing the manuscript.

\section{Additional material}

\section{Additional file 1}

Up-regulated gene list with fold change (FC). The data provided here represent the statistical analysis (SAM) of up-regulated genes in the muscles of MSTN-null mice.

Click here for file

[http://www.biomedcentral.com/content/supplementary/1471-

2164-10-196-S1.doc]

\section{Additional file 2}

Down-regulated gene list with fold change (FC). The data provided here represent the statistical analysis (SAM) of down-regulated genes in the muscles of MSTN-null mice.

Click here for file

[http://www.biomedcentral.com/content/supplementary/1471-

2164-10-196-S2.doc]

\section{Acknowledgements}

The authors thank members of the U533 Inserm group's (Faculté de Médecine de Nantes France) for providing the Myochips and bioinformatics tools and for skilled technical advice; $G$ Gentès, N Dunoyer and $C$ Barboiron for excellent technical assistance in molecular biology, $C$ Chambon (Plateforme de Theix "Exploration du Métabolisme: des gènes aux métabolites") for protein identification. This work was supported by a grant from the French Muscular Dystrophy Association (AFM).

\section{References}

I. Guttridge : Signaling pathways weigh in on decisions to make or break skeletal muscle. Curr Opin Clin Nutr Metab Care 2004, 7(4):443-450.

2. Tsuchida K: Activins, Myostatin and Related TGF-beta Family Members as Novel Therapeutic Targets for Endocrine, Metabolic and Immune Disorders. Curr Drug Targets Immune Endocr Metabol Disord 2004, 4:157-166.

3. Sillence MN: Technologies for the control of fat and lean deposition in livestock. Vet J 2004, 167(3):242-257.

4. Holmes JH, Ashmore CR: A histochemical study of development of muscle fiber type and size in normal and "double muscled" cattle. Growth 1972, 36:35I-372.

5. Grobet L, Martin LJ, Poncelet D, Pirottin D, Brouwers B, Riquet J, Schoeberlein A, Dunner S, Menissier F, Massabanda J, et al.: A deletion in the bovine myostatin gene causes the double-muscled phenotype in cattle. Nat Genet 1997, 17:7I-74.

6. Mosher DS, Quignon P, Bustamante CD, Sutter NB, Mellersh CS, Parker HG, Ostrander EA: A Mutation in the Myostatin Gene Increases Muscle Mass and Enhances Racing Performance in Heterozygote Dogs. PLoS Genetics 2007, 3(5):79.

7. McPherron AC, Lawler AM, Lee S-J: Regulation of skeletal muscle mass in mice by a new TGF-beta superfamily member. Nature 1997, 387(6628):83-90.

8. Schuelke M, Wagner KR, Stolz LE, Hubner C, Riebel T, Komen W, Braun T, Tobin JF, Lee S-J: Myostatin Mutation Associated with Gross Muscle Hypertrophy in a Child. N Engl J Med 2004, 350(26):2682-2688.

9. Grobet L, Pirottin D, Farnir F, Poncelet D, Royo LJ, Brouwers B, Christians E, Desmecht D, Coignoul F, Kahn R, et al.: Modulating skeletal muscle mass by postnatal, muscle-specific inactivation of the myostatin gene. Genesis 2003, 35(4):227-238.

10. Thomas M, Langley B, Berry C, Sharma M, Kirk S, Bass J, Kambadur R: Myostatin, a Negative Regulator of Muscle Growth, Functions by Inhibiting Myoblast Proliferation. J Biol Chem 2000, 275(5I):40235-40243.

II. Taylor WE, Bhasin S, Artaza J, Byhower F, Azam M, Willard DH Jr, Kull FC Jr, Gonzalez-Cadavid N: Myostatin inhibits cell proliferation and protein synthesis in C2CI 2 muscle cells. Am J Physiol Endocrinol Metab 200I, 280(2):E22I-228.

12. Rios R, Carneiro I, Arce VM, Devesa J: Myostatin is an inhibitor of myogenic differentiation. Am J Physiol Cell Physiol 2002, 282(5):C993-999.

13. Joulia-Ekaza D, Cabello G: Myostatin regulation of muscle development: Molecular basis, natural mutations, physiological aspects. Exp Cell Res 2006, 3 I 2:240 I-24I4.

14. Joulia D, Bernardi H, Garandel V, Rabenoelina F, Vernus B, Cabello G: Mechanisms involved in the inhibition of myoblast proliferation and differentiation by myostatin. Experimental Cell Research 2003, 286(2):263-275.

15. McCroskery S, Thomas M, Maxwell L, Sharma M, Kambadur R: Myostatin negatively regulates satellite cell activation and self-renewal. J Cell Biol 2003, I62(6): I I35-I I47.

16. McFarland: The role of myostatin in chicken (Gallus domesticus) myogenic satellite cell proliferation and differentiation. Gen Comp Endocrinol 2007, 1 5 1:35 I-357.

17. Steelman CA, Recknor JC, Nettleton D, Reecy JM: Transcriptional profiling of myostatin-knockout mice implicates Wnt signaling in postnatal skeletal muscle growth and hypertrophy. Faseb J 2006, 20(I):580-582.

18. Carlson CJ, Booth FW, Gordon SE: Skeletal muscle myostatin mRNA expression is fiber-type specific and increases during hindlimb unloading. Am J Physiol 1999, 277(2 pt 2):R60I-606. 
19. Solomon AM, Bouloux PMG: Modifying muscle mass - the endocrine perspective. J Endocrinol 2006, I 9 I (2):349-360.

20. Reisz-Porszasz S, Bhasin S, Artaza JN, Shen R, Sinha-Hikim I, Hogue A, Fielder TJ, Gonzalez-Cadavid NF: Lower skeletal muscle mass in male transgenic mice with muscle-specific overexpression of myostatin. Am J Physiol Endocrinol Metab 2003, 285(4):E876-888.

21. Durieux A-C, Amirouche A, Banzet S, Koulmann N, Bonnefoy R, Pasdeloup M, Mouret C, Bigard X, Peinnequin A, Freyssenet D: Ectopic expression of myostatin induces atrophy of adult skeletal muscle by decreasing muscle gene expression. Endocrinology 2007, I48(7):3|40-3|47.

22. Ohsawa $Y$, Hagiwara $H$, Nakatani M, Yasue A, Moriyama K, Murakami T, Tsuchida K, Noji S, Sunada Y: Muscular atrophy of caveolin-3. deficient mice is rescued by myostatin inhibition. J Clin Invest 2006, II 6(II):2924-2934.

23. Gilson H, Schakman O, Combaret L, Lause P, Grobet L, Attaix D, Ketelslegers JM, Thissen JP: Myostatin Gene Deletion Prevents Glucocorticoid-Induced Muscle Atrophy. Endocrinology 2007 I48(I):452-460.

24. McFarlane C, Plummer E, Thomas M, Hennebry A, Ashby M, Ling N, Smith H, Sharma M, Kambadur R: Myostatin induces cachexia by activating the ubiquitin proteolytic system through an NF. kappaB-independent, FoxOl-dependent mechanism. J Cell Physiol 2006, 209:50I-5I4.

25. McMahon CD, Popovic L, Oldham JM, Jeanplong F, Smith HK, Kambadur R, Sharma M, Maxwell L, Bass J]: Myostatin-deficient mice lose more skeletal muscle mass than wild-type controls during hindlimb suspension. Am J Physiol Endocrinol Metab 2003, 285(I):E82-87.

26. Hocquette J-F, Bas P, Bauchart D, Vermorel M, Geay Y: Fat partitioning and biochemical characteristics of fatty tissues in relation to plasma metabolites and hormones in normal and double-muscled young growing bulls. Comp Biochem Physiol $A$ Molec Integr Physiol 1999, I 22(I): 127-138.

27. Bouley J, Meunier B, Chambon C, De Smet S, Hocquette JF, Picard B: Proteomic analysis of bovine skeletal muscle hypertrophy. Proteomics 2005, 5(2):490-500.

28. Cassar-Malek I, Passelaigue F, Bernard C, Leger J, Hocquette J-F: Target genes of myostatin loss-of-function in muscles of late bovine fetuses. BMC Genomics 2007, 8(I):63.

29. Steelman CA, Recknor JC, Nettleton D, Reecy JM: Transcriptional profiling of myostatin-knockout mice implicates Wnt signaling in postnatal skeletal muscle growth and hypertrophy. FASEB J 2006, 20(3):580-582.

30. Vandebrouck A, Sabourin J, Rivet J, Balghi H, Sebille S, Kitzis A, Raymond G, Cognard C, Bourmeyster N, Constantin B: Regulation of capacitative calcium entries by \{alpha\} I-syntrophin: association of TRPCI with dystrophin complex and the PDZ domain of \{alpha\} I-syntrophin. FASEB J 2007, 2 I (2):608-6I7.

31. Chan TO, Rittenhouse SE, Tsichlis PN: Akt/PKB and other D3 phosphoinositide-regulated kinases: Kinase Activation by Phosphoinositide-Dependent Phosphorylation. Annu Rev Biochem 1999, 68(I):965-1014.

32. Lev N, Roncevich D, Ickowicz D, Melamed E, Offen D: Role of DJ-I in Parkinson's disease. J Mol Neurosci 2006, 29(3):2 15-225.

33. Kim RH, Peters M, Jang Y, Shi W, Pintilie M, Fletcher GC, DeLuca C Liepa J, Zhou L, Snow B, et al: DJ-I, a novel regulator of the tumor suppressor PTEN. Cancer Cell 2005, 7(3):263-273.

34. Tang B, Xiong H, Sun P, Zhang Y, Wang D, Hu Z, Zhu Z, Ma H, Pan $Q$, Xia J-h, et al: Association of PINKI and DJ-I confers digenic inheritance of early-onset Parkinson's disease. Hum Mol Genet 2006, I5(I I): |8|6-1825.

35. Cully M, You H, Levine AJ, Mak TW: Beyond PTEN mutations: the PI3K pathway as an integrator of multiple inputs during tumorigenesis. Nat Rev Cancer 2006, 6(3): 184-192.

36. Frost RA, Lang $\mathrm{CH}$ : Protein kinase B/Akt: a nexus of growth factor and cytokine signaling in determining muscle mass. Appl Physiol 2007, 103(I):378-387.

37. Leger B, Cartoni R, Praz M, Lamon S, Deriaz O, Crettenand A, Gobelet $C$, Rohmer $\mathrm{P}$, Konzelmann M, Luthi $\mathrm{F}$, et al: Akt signalling through GSK-3\{beta\}, mTOR and Foxol is involved in human skeletal muscle hypertrophy and atrophy. J Physiol 2006, 576(3):923-933.

38. Amirouche A, Durieux A-C, Banzet S, Koulmann N, Bonnefoy R, Mouret C, Bigard X, Peinnequin A, Freyssenet D: Down-Regulation of Akt/Mammalian Target of Rapamycin Signaling Pathway in Response to Myostatin Overexpression in Skeletal Muscle. Endocrinology 2009, I50( I):286-294.

39. Yang W, Zhang Y, Li Y, Wu Z, Zhu D: Myostatin Induces Cyclin DI Degradation to Cause Cell Cycle Arrest through a Phosphatidylinositol 3-Kinase/AKT/GSK-3beta Pathway and Is Antagonized by Insulin-like Growth Factor I. J Biol Chem 2007, 282(6):3799-3808.

40. Stitt TN, Drujan D, Clarke BA, Panaro F, Timofeyva Y, Kline WO, Gonzalez M, Yancopoulos GD, Glass DJ: The IGF-I/PI3K/Akt pathway prevents expression of muscle atrophy-induced ubiquitin ligases by inhibiting FOXO transcription factors. Mol Cell 2004, 14:395-403.

4I. Velden JLJ van der, Langen RCJ, Kelders MCJM, Wouters EFM, Janssen-Heininger YMW, Schols AMWJ: Inhibition of glycogen synthase kinase-3 3 beta\} activity is sufficient to stimulate myogenic differentiation. Am J Physiol Cell Physiol 2006, 290(2): C453-462.

42. Fan G-C, Chu G, Mitton B, Song Q, Yuan Q, Kranias EG: Small Heat-Shock Protein Hsp20 Phosphorylation Inhibits \{beta\}Agonist-Induced Cardiac Apoptosis. Circ Res 2004, 94(II): 1474-1482

43. Kaul SC, Deocaris CC, Wadhwa R: Three faces of mortalin: A housekeeper, guardian and killer. Exp Geront 2007, 42(4):263-274

44. Wadhwa KTaSCK: An Hsp70 family chaperone, mortalin/ mthsp70/PBP74/Grp75: what, when, and where? Cell Stress Chaperones 2002, 7(3):309-316.

45. Wadhwa R, Takano S, Kaur K, Deocaris CC, Pereira-Smith OM, Reddel RR, Kaul SC: Upregulation of mortalin/mthsp70/Grp75 contributes to human carcinogenesis. Int J Cancer 2006, I I 8( I 2):2973-2980.

46. Sugimoto A, Hozak RR, Nakashima $T$, Nishimoto $T$, Rothman JH: dad-I, an endogenous programmed cell death suppressor in Caenorhabditis elegans and vertebrates. EMBO J 1995, 14(18):4434-444I.

47. Nakashima T, Sekiguchi T, Kuraoka A, Fukushima K, Shibata $Y$, Komiyama S, Nishimoto T: Molecular cloning of a human cDNA encoding a novel protein, DADI, whose defect causes apoptotic cell death in hamster BHK2I cells. Mol Cell Biol 1993, I3(I0):6367-6374.

48. Gurbuxani S, Xu Y, Keerthivasan G, Wickrema A, Crispino JD: Differential requirements for survivin in hematopoietic cell development. Proc Natl Acad Sci USA 2005, I 02(32): I | 480-I | 485.

49. Yarm FR: Plk Phosphorylation Regulates the Microtubule-Stabilizing Protein TCTP. Mol Cell Biol 2002, 22( I 7):6209-622I.

50. Bommer U-A, Thiele B-J: The translationally controlled tumour protein (TCTP). Int J Biochem Cell Biol 2004, 36(3):379-385.

5I. Porter GW, Khuri FR, Fu H: Dynamic 14-3-3/client protein interactions integrate survival and apoptotic pathways. Sem Cancer Biol 2006, I 6(3): 193-202.

52. Datta SR, Katsov A, Hu L, Petros A, Fesik SW, Yaffe MB, Greenberg ME: 14-3-3 Proteins and Survival Kinases Cooperate to Inactivate BAD by BH3 Domain Phosphorylation. Mol Cell 2000, 6(I):4I-5I.

53. Haar EV, Lee S-i, Bandhakavi S, Griffin TJ, Kim D-H: Insulin signalling to mTOR mediated by the Akt/PKB substrate PRAS40. Nat Cell Biol 2007, 9(3):316-323.

54. Pozuelo Rubio M, Geraghty KM, Wong BHC, Wood NT, Campbell DG, Morrice N, Mackintosh C: 14-3-3-affinity purification of over 200 human phosphoproteins reveals new links to regulation of cellular metabolism, proliferation and trafficking. Biochem J 2004, 379(2):395-408.

55. Ríos R, Carneiro I, Arce VM, Devesa J: Myostatin Regulates Cell Survival during C2CI 2 Myogenesis. Biochem Biophys Res Commun 200I, 280(2):56I-566.

56. Yang W, Zhang Y, Ma G, Zhao X, Chen Y, Zhu D: Identification of gene expression modifications in myostatin-stimulated myoblasts. Biochem Biophys Res Commun 2005, 326(3):660-666.

57. Adhihetty PJ, Hood DA: Mechanisms of Apoptosis in Skeletal Muscle. Basic Appl Myol 2003, I3(4): I7I- I79.

58. Koçtürk S, Kayatekin B, Resmi H, Açýkgöz O, Kaynak C, Özer E: The apoptotic response to strenuous exercise of the gastrocnemius and soleus muscle fibers in rats. Eur J Appl Physiol 2008, 102(5):5 I5-524.

59. Spencer MJ, Walsh C, Dorshkind KA, Rodriguez EM, Tidball JG: Myonuclear apoptosis in dystrophic mdx muscle occurs by per- 
forin-mediated cytotoxicity. J Clin Invest 1997, 99(II):2745-275I.

60. Dupont-Versteegden EE: Apoptosis in muscle atrophy: Relevance to sarcopenia. Exp Geront 2005, 40(6):473-48I.

61. Busquets S, Deans C, Figueras M, Moore-Carrasco R, López-Soriano $\mathrm{FJ}$, Fearon $\mathrm{KCH}$, Argilés JM: Apoptosis is present in skeletal muscle of cachectic gastro-intestinal cancer patients. Clin Nutr 2007, 26(5):614-618.

62. Allen DL, Roy RR, Edgerton VR: Myonuclear domains in muscle adaptation and disease. Muscle Nerve 1999, 22(10): 1350-1360.

63. Primeau A, Adhihetty PJ, Hood DA: Apoptosis in heart and skeletal muscle. Can J Appl Physiol 2002, 27(4):349-395.

64. Tusher VG, Tibshirani R, Chu G: Significance analysis of microarrays applied to the ionizing radiation response. Proc Natl Acad Sci 200I, 98:5II6-5I20.

65. Mera R, Thompson H, Prasad C: How to calculate sample size for an experiment: A case-based description. Nutr Neurosci 1998, I:87-91.

66. Lenth RV: Statistical power calculations. J Anim Sci 2007, 85(I3_suppl):E24-29.

67. Bouley J, Chambon C, Picard B: Mapping of bovine skeletal muscle proteins using two-dimensional gel electrophoresis and mass spectrometry. Proteomics 2004, 4(6): | $8 \mid$ | I- 824.

68. Meunier B, Bouley J, Piec I, Bernard C, Picard B, Hocquette J-F: Data analysis methods for detection of differential protein expression in two-dimensional gel electrophoresis. Anal Biochem 2005, 340(2):226-230.

69. Picard B, Duris M-P, Jurie C: Caractérisation des chaînes lourdes de myosine dans le muscle de bovin. INRA Prod Anim 1998, II(2): I50-I52.

Publish with Biomed Central and every scientist can read your work free of charge

"BioMed Central will be the most significant development for disseminating the results of biomedical research in our lifetime. "

Sir Paul Nurse, Cancer Research UK

Your research papers will be:

- available free of charge to the entire biomedical community

- peer reviewed and published immediately upon acceptance

- cited in PubMed and archived on PubMed Central

- yours - you keep the copyright

Submit your manuscript here:

http://www.biomedcentral.com/info/publishing_adv.asp
BiolMedcentral 